\title{
Stimulatory Effect of Serum from Diabetic Patients on Insulin Release from Mouse Pancreatic Islets Maintained in Tissue Culture
}

\author{
J. H. Nielsen, C. Eff, T. Deckert, and A. Andersson ${ }^{1}$ \\ Hagedorn Research Laboratory and Steno Memorial Hospital, Gentofte, Denmark, \\ and ${ }^{1}$ Department of Histology, University of Uppsala, Uppsala, Sweden
}

Summary. Islets of Langerhans from NMRI-mice were kept for one week in tissue culture in medium supplemented with human serum obtained from either normal healthy subjects or newly diagnosed juvenile diabetic patients before insulin treatment. Islets cultured in diabetic serum released more insu. lin than islets cultured in normal serum, whether tissue culture medium 199 with $5.5-8.3 \mathrm{mmol} / 1$ glucose and $10 \%$ serum, or culture medium RPMI 1640 with $11 \mathrm{mmol} / 1$ glucose and $0.5 \%$ serum were used. Islets kept for one week in culture with diabetic serrum did not show any decrease in DNA content or glucose induced insulin secretion and biosynthesis. It is concluded that serum from newly diagnosed insulindependent diabetic patients stimulates insulin release from isolated mouse islets kept in tissue culture. The underlying mechanism is unknown.

Key words: Pancreatic islets, tissue culture, diabetic serum, beta-cell function.

The initial events in the pathogenesis of diabetes mellitus leading to impairment of the beta-cell function are not known. Provoking factors, such as infection, stress, or diet may induce hormonal, metabolic or immunological changes, which affect the function of the beta-cell. Depending on the genetic background, the result may be an impairment and atrophy of the beta-cells. Development of methods for isolation and maintenance in tissue culture of islets of Langerhans for long periods [3] made it possible to study not only acute effects but also chronic effects of metabolites and hormones on insulin secretion and biosynthesis in vitro.
Since it may well be that the initial diabetogenic event is reflected in changes in the blood composition of diabetic patients, the present study was undertaken to determine whether serum from newly diagnosed patients with insulin-dependent diabetes mellitus before treatment contains factors capable of influencing beta-cell function.

In the conventional islet culture system with medium 199 or RPMI 1640 supplemented with calf serum, the calf serum was replaced with serum from either normal human subjects or diabetic patients. However, since the gluçose concentration has been shown to have a strong influence on the beta-cell function [1], the medium was corrected for any differences in glucose concentration between normal and diabetic sera.

\section{Materials and Methods}

\section{Sera}

Control sera were collected from 5 normal female and 5 normal male subjects. Diabetic sera were collected before insulin treatment from 10 consecutively newly diagnosed insulin-dependent diabetics aged 15-34 years. Their metabolic data as given in Table 1. All sera, except no. 5 and 6 which were too lipaemic, were sterilized by filtration (Millipore Millex $0.22 \mu \mathrm{m}$ ) and stored in aliquots at $-20^{\circ} \mathrm{C}$. Because of limited supply of some of the sera not all of them were tested individually in all types of experiments. In some experiments pooled sera were employed, either of 10 normal females (no. 1) or 10 normal males (no. 2) or pools mixed of two parts no. 1 and three parts no. 2 (N-pool) or equal parts of the diabetic sera no. 4, 8, 9, 10 and 12 (D-pool) having the same sex distribution.

\section{Insulin Degradation}

The degradation of insulin in the culture medium was tested by adding $100 \mathrm{ng} / \mathrm{ml}$ mouse insulin to the media supplemented with $10 \%$ of either $\mathrm{N}$-pool or $\mathrm{D}$-pool and following the immunoreac- 
Table 1. Metabolic parameters of normal and diabetic sera. Sera 1 and 2 were pools from 10 normal $(\mathrm{N})$ females $(\mathfrak{f})$ and males ( $\mathrm{m}$ ), respectively. Sera 3 to 12 were individual sera taken from 10 consecutive newly diagnosed, insulin dependent diabetics (D) before insulin treatment. Corticosteroids were determined by a fluorometric method [22] and islet cell antibodies of the IgG class determined as described by Bottazzo et al. [6]. + + : strongly positive, + : positive, - : negative, n. d.: not determined

\begin{tabular}{|c|c|c|c|c|c|c|}
\hline Serum & $\begin{array}{l}\text { Subject } \\
\text { and sex }\end{array}$ & $\begin{array}{l}\text { Glucose } \\
\mathrm{mmol} / 1\end{array}$ & $\begin{array}{l}\text { 3-hydroxy- } \\
\text { butyrate } \mathrm{mmol} / 1\end{array}$ & $\begin{array}{l}\text { Triglyceride } \\
\mathrm{mmol} / \mathrm{l}\end{array}$ & $\begin{array}{l}\text { Corticosteroids } \\
\mu \mathrm{g} / 1\end{array}$ & $\begin{array}{l}\text { Islet cell } \\
\text { antibodies }\end{array}$ \\
\hline 1 & $\mathrm{Nf}$ & 4.4 & 0.27 & 0.73 & 183 & - \\
\hline 2 & $\mathrm{~N} \mathrm{~m}$ & 4.8 & 0.07 & 1.15 & 181 & - \\
\hline 3 & $\mathrm{D} \mathrm{m}$ & 16.3 & 0.27 & 1.03 & 253 & ++ \\
\hline 4 & $\mathrm{Df}$ & $15: 1$ & 0.25 & 0.86 & 246 & - \\
\hline 5 & $\bar{D} \mathrm{~m}$ & 27.0 & 7.45 & 8.49 & 232 & n. d. \\
\hline 6 & $\mathrm{D} \mathrm{m}$ & 24.2 & 3.72 & 15.02 & 454 & - \\
\hline 7 & $\mathrm{D} \mathrm{m}$ & 18.0 & 1.34 & 6.50 & 253 & - \\
\hline 8 & $\mathrm{D} \mathrm{m}$ & 17.8 & 0.66 & 1.80 & 298 & - \\
\hline 9 & $\mathrm{D} \mathrm{m}$ & 14.2 & 2.55 & 0.91 & 306 & - \\
\hline 10 & $\mathrm{D} \mathrm{m}$ & 12.3 & 0.77 & 0.98 & 312 & - \\
\hline 11 & $\overline{D F}$ & 11.7 & 0.72 & 0.95 & 239 & n. d. \\
\hline 12 & $D f$ & 11.7 & 2.11 & 0.91 & 214 & + \\
\hline
\end{tabular}

Table 2. Degradation of mouse insulin, $100 \mathrm{ng} / \mathrm{ml}$, added to medium 199 with $6.4 \mathrm{mmol} / 1$ glucose and $10 \%$ diabetic serum or normal human serum or normal human serum heat-inactivated at $56^{\circ} \mathrm{C}$ for $30 \mathrm{~min}$. The dishes were incubated at $37^{\circ} \mathrm{C}$ for 3 days and samples were taken each day. The values are given in per cent of the initial value in 2 dishes of each medium (mean \pm half-range)

\begin{tabular}{lrll}
\hline Serum sample & \multicolumn{1}{c}{ Day 1} & Day 2 & Day 3 \\
\hline D-pool & $103 \pm 1$ & $107 \pm 4$ & $110 \pm 3$ \\
N-pool & $99 \pm 9$ & $109 \pm 6$ & $118 \pm 3$ \\
N-pool heat-inact. & $103 \pm 1$ & $105 \pm 4$ & $113 \pm 5$ \\
\hline
\end{tabular}

tive insulin content during incubation at $37^{\circ} \mathrm{C}$ for up to 3 days. No significant loss could be demonstrated in any medium (Table 2).

\section{Islet Culture}

Islets of Langerhans from male NMRI mice starved overnight were isolated by the method of Andersson and Hellerström [3]. The fine-cut pancreases were treated with $10 \mathrm{mg} / \mathrm{ml}$ collagenase (Type I, Sigma Chemical Company, St. Louis, Mo., USA) in Hanks' Balanced Salt Solution (Flow Laboratories, Irvine, Scotland, UK) supplemented with $25 \mathrm{mmol} / 1$ HEPES ( $N$-2-hydroxyethylpiperazine- $N$ 2-ethane) ( $\mathrm{pH} \mathrm{7.4)}$ ) for $10-15 \mathrm{~min}$ by hand shaking, or with $1.5 \mathrm{mg} / \mathrm{ml}$ collagenase for $15-20 \mathrm{~min}$ in a mechanical shaker at $37^{\circ} \mathrm{C}$. After harvesting with a braking pipette under stereo microscope the islets were placed in plastic tissue culture dishes (NUNC, Roskilde, Denmark) containing medium 199 (Flow) with or without $5.5 \mathrm{mmol} / \mathrm{l}$ glucose depending on the desired final glucose concentration; the islets were allowed to attach to the bottom. The medium was supplemented with $10 \%$ normal or diabetic serum. In some experiments the islets were placed in bacteriological Petri dishes (NUNC), not allowing attachment of islets, with culture medium RPMI 1640 (Flow) containing $11 \mathrm{mmol} / 1$ glucose and supplemented with $0.5 \%$ normal or diabetic serum. All incubations were carried out at $37^{\circ} \mathrm{C}$ in a humidified atmosphere of $5 \%$ carbon dioxide.
The culture medium was changed on day 3 and 5 , and insulin determined by radioimmunoassay (RIA) employing either the double antibody method [12] or ethanol precipitation [14] with mouse or rat insulin (Novo Research Laboratory, Copenhagen, Denmark) as standards.

On day 7 the islets were harvested either directly or, when attached, after scraping with a "rubber policeman" (Quickfit, Staffs., UK) to determine the content of insulin and DNA [10], or to be used in short-term incubations to study release and biosynthesis of insulin.

\section{Insulin Secretion}

Groups of 10 islets were placed in small glass cups with $300 \mu \mathrm{l}$ Krebs-Ringer-bicarbonate solution containing. $0.2 \%$ human serum albumin (Behringwerke, Marburg, Germany), and $5 \mathrm{mmol} / 1$ theophylline supplemented with $2.5,10$ or $20 \mathrm{mmol} / \mathrm{l}$ glucose. The glass cups were placed in $25 \mathrm{ml}$ stoppered glass vials previously gassed with a mixture of $95 \%$ oxygen and $5 \%$ carbon dioxide. They were placed in a metabolic shaker at $37^{\circ} \mathrm{C}$ for $2 \mathrm{~h}$, when the medium was decanted for determination of insulin.

\section{Insulin Biosynthesis}

Groups of 5 islets were placed in small cups containing $100 \mathrm{ul}$ phenylalanine-free Eagles minimal essential medium (Gibco BioCult Ltd., Paisley, Scotland, UK) supplemented with $16.7 \mathrm{mmol} / 1$ glucose and $3.7 \mathrm{MBq} / \mathrm{ml}\left[{ }^{3} \mathrm{H}\right]$-phenylalanine (Radiochemical Centre, UK). After $2 \mathrm{~h}$ of incubation the islets were homogenised and the incorporation of radioactivity in insulin and proinsulin determined by a solid phase assay [5].

\section{Results}

When islets were cultured in medium 199 containing $10 \%$ serum from either 10 normal individuals or 7 newly diagnosed diabetic patients (sera 4, 5 and 6 not tested) at $8.3 \mathrm{mmol} / 1$ glucose the insulin release was 


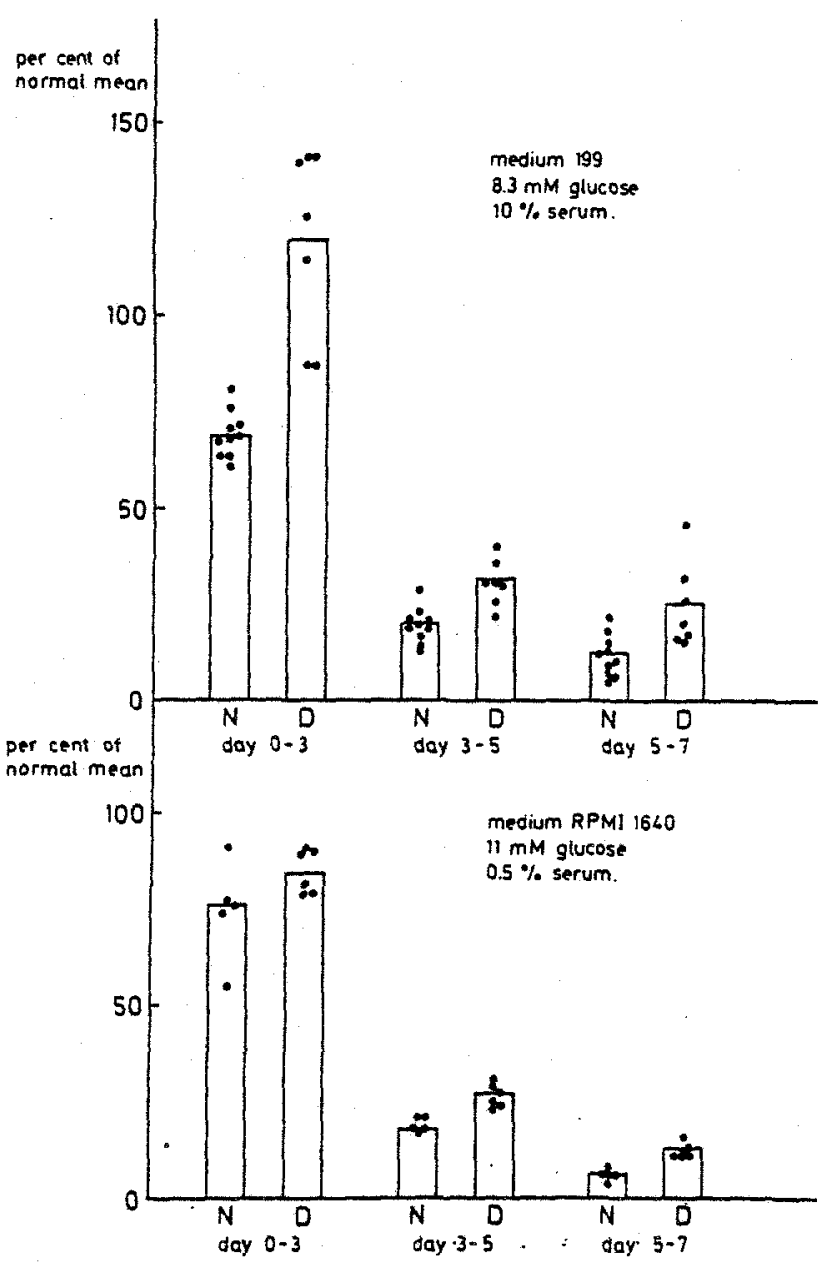

Fig. 1. Effect of normal and diabetic sera on insulin release from mouse pancreatic islets cultured in medium 199 with $8.3 \mathrm{mmol} / 1$ glucose and $10 \%$ serum (upper panel) and medium RPMI 1640 with $11 \mathrm{mmol} / 1$ glucose and $0.5 \%$ serum (lower panel). In the upper panel each of the ten normal (N) sera and seven diabetic (D) sera (no. 3, 7, 8, 9, 10,11 and 12) were tested in two separate experiments, and the insulin release was calculated as per cent of the mean total insulin release from the isiets cultured in the normal sera within each experiment (100\% correspond to $49.1 \mathrm{ng}$ insulin per islet in 7 days). By day 3,5 and 7 the islets cultured in diabetic sera had released significantly more insulin than those cultured in normal sera $(p<0.01$, Wilcoxon test). In the lower panel five normal sera were compared with six diabetic sera (no. $7,8,9,10$, 11 and 12) in two separate experiments and the insulin release was expressed as above (100\% correspond to $109.1 \mathrm{ng}$ insulin per islet in 7 days). The insulin release from the islets cultured in the diabetic sera was significantly higher than from those cultured in normal sera at day 5 and 7 ( $p<0.01$, Wilcoxon test), while no significant difference was found on day 3

significantly higher from the islets kept in the diabetic serum than from those in normal serum (Fig. 1, upper panel).

The stimulatory effect did not seem to depend on the culture medium since an increased insulin secretion was also seen when 6 of the diabetic sera were compared with 5 of the normal sera added to medium RPMI 1640 at a concentration of only $0.5 \%$ (Fig. 1 lower panel).

In another series of experiments each of the 10 diabetic sera were compared with a pool of normal sera of the corresponding sex at the glucose concentration resulting from the actual content of the sera added to medium 199. The insulin release from the islets kept in diabetic sera was in all cases higher than from the control islets (Fig. 2). Islets in medium containing normal serum ( $\mathrm{N}$-pool) were incubated at glucose concentrations varying from $5.5-8.0 \mathrm{mmol} / 1$ (Fig. 2). The shaded area indicates the expected $95 \%$ confidence limits for the insulin release of islets cultured in individual normal sera, as predicted from the coefficient of variation of the data in Figure 1. Over the span of glucose concentrations all diabetic sera but one (no. 4) induced a significant increase in the insulin release.

There was no difference in DNA-content between islets cultured in diabetic and normal sera, but a small reduction $(p<0.02)$ in the insulin content after culture in diabetic serum was noted (Fig. 3). The increased release and lower insulin content resulted in an increased to content ratio after exposure to diabetic serum.

The ability of the islets to synthesize insulin after the culture in diabetic sera seemed not to be impaired (Table 3). In one serum sample (no. 3), however, the insulin synthesis was lower than in the others, although there was no reduction in \% of total protein synthesis. It is notable that serum sample no. 3 had a high titre of islet-cell antibodies.

In another series of experiments (Table 4) the islets were cultured in medium 199 supplemented with $10 \% \mathrm{~N}$-pool or $\mathrm{D}$-pool and adjusted to $6.4 \mathrm{mmol} / 1$ glucose. Not only was the release of insulin to the culture medium higher in the presence of diabetic serum, but there was also an increased release in response to $2.5,10$ or $20 \mathrm{mmol} / 1$ glucose with $5 \mathrm{mmol} / \mathrm{l}$ theophylline after one week in tissue culture.

\section{Discussion}

The increased insulin concentration in the culture media containing diabetic serum was apparently not caused by a difference in insulin degradation rate since no degradation of added insulin could be detected in medium supplemented with $10 \%$ normal or diabetic serum (Table 2).

At the concentrations employed the stimulation by diabetic serum does not reflect a $\beta$-cell destruction since DNA-content (Fig. 3), insulin biosynthesis 


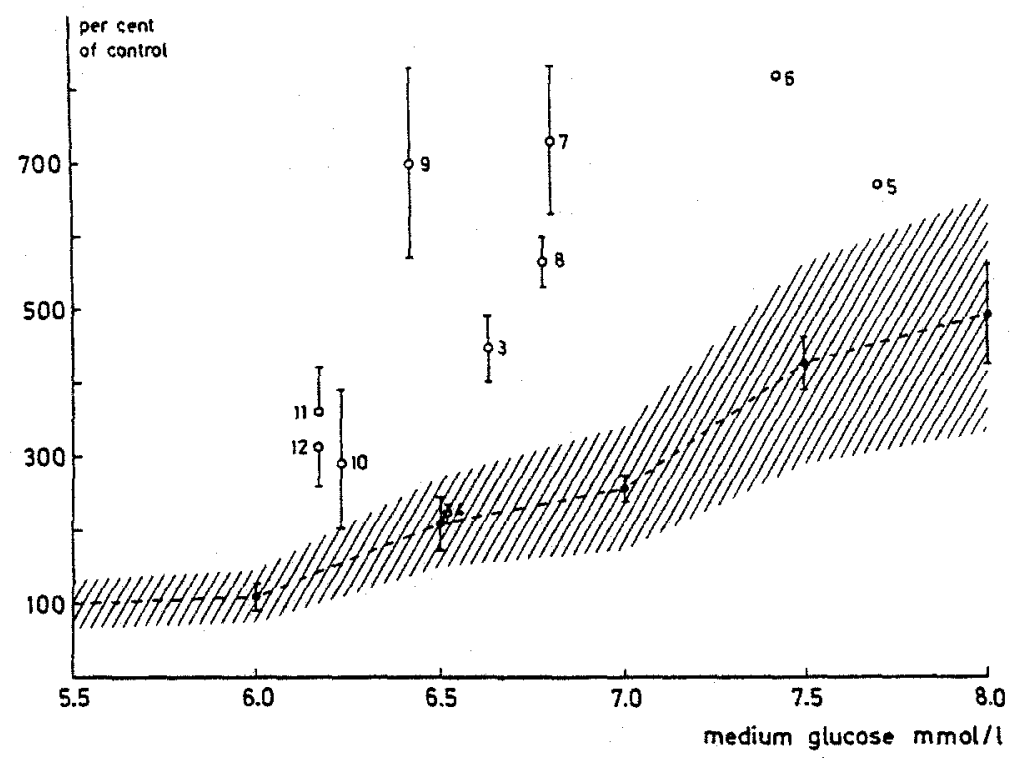

Fig. 2. Effect of normal and diabetic serum on insulin release from mouse pancreatic islets cultured in medium 199 at the glucose concentrations indicated on the abcissa. Each of the diabetic sera indicated by numbers was tested in $1-4$ separate experiments with a normal serum pool ( $\mathrm{N}$-pool) at $5.5 \mathrm{mmol} / 1$ glucose as control. The total release at day 3 and 5 from the islets cultured in the diabetic serum was calculated as per cent of the release from the islets cultured in the normal serum and given as the mean $\pm \mathrm{SEM}$. The release of insulin from islets cultured in N-pool at different glucose concentrations is connected by the dotted line. The hatched area indicates the $95 \%$ confidence limits calculated from the coefficient of variation of the insulin release from islets cultured in the presence of the ten individual normal sera shown in the upper panel of Figure 1. All diabetic sera except one (no. 4) induced a significantly higher insulin release than expected from normal sera

DNA coritent insutin content

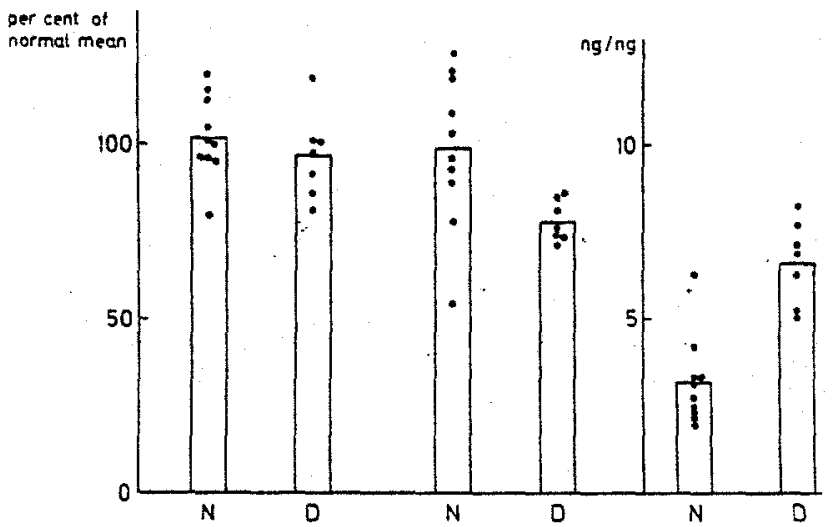

Fig. 3. Effect of normal and diabetic sera on DNA and insulin content of mouse pancreatic islets cultured for one week in medium 199 with $8.3 \mathrm{mmol} / 1$ glucose and $10 \%$ serum (cf. Fig. 1 upper panel). No significant difference was found in the DNA content of the islets cultured in normal and diabetic sera, while the insulin content was lower in the islets cultured in diabetic sera $(p<$ 0.02 , Wilcoxon test) $(100 \%$ of the DNA and insulin content correspond to 31.6 and $24.0 \mathrm{ng}$ per islet, respectively). When the insulin release to the medium given in ng per islet per week was expressed per ng islet insulin content the islets cultured in diabetic sera produced significantly more insulin than those cultured in normal sera $(p<0.01$, Wilcoxon test)

(Table 3) and insulin response to glucose and theophylline (Table 4) were unaffected or stimulated. In contrast to dispersed islets cells from non-inbred ob/ ob mouse islets [20] the present islet culture system did not seem to be sensitive to the $\beta$-cytotoxicity of serum from both normal and diabetic human sub-
Table 3. Incorporation of ${ }^{3} \mathrm{H}$-phenylalanine into proinsulin and insulin of islets cultured in normal and diabetic sera. After one week, islets were harvested and incubated for $2 \mathrm{~h}$ in phenylalanine-free medium supplemented with $3.7 \mathrm{MBq} / \mathrm{ml}\left[{ }^{3} \mathrm{H}\right]$-phenylalanine and $16.7 \mathrm{mmol} / \mathrm{l}$ glucose. The results are given as mean \pm SEM of 4 individual experiments. The first column shows the radioactivity in the proinsulin-insulin fraction bound to the immunosorbent, and the second column shows this fraction expressed as a percentage of the total radioactivity in the TCAprecipitated proteins (total protein synthesis)

\begin{tabular}{llll}
\hline Serum & $\begin{array}{l}\text { Subject } \\
\text { and sex }\end{array}$ & $\begin{array}{l}\text { CPM } \times 10^{-3} \\
\text { per } 10 \text { islets }\end{array}$ & $\begin{array}{l}\% \text { of total } \\
\text { radioactivity }\end{array}$ \\
\hline 1 & N f & $20.3 \pm 7.2$ & $13.6 \pm 3.3$ \\
2 & N m & $19.0 \pm 2.9$ & $16.2 \pm 1.4$ \\
3 & D m & $14.2 \pm 2.9$ & $18.3 \pm 2.3$ \\
4 & D f & $17.5 \pm 3.0$ & $16.3 \pm 3.6$ \\
8 & D m & $20.7 \pm 3.3$ & $16.4 \pm 2.1$ \\
9 & D m & $21.8 \pm 2.8$ & $18.9 \pm 1.2$ \\
10 & D m & $20.4 \pm 2.3$ & $17.4 \pm 2.1$ \\
11 & D f & $17.3 \pm 1.4$ & $18.3 \pm 0.7$ \\
12 & D f & $17.3 \pm 3.3$ & $18.8 \pm 3.3$ \\
\hline
\end{tabular}

jects. Under similar conditions as those described here, we could maintain the $\beta$-cell function of isolated islets for up to two years [23].

In isolated rat islets Hahn et al. [11] found a positive correlation between the capacity of diabetic sera to stimulate insulin release and the insulin-antibody titre of these sera. This does not seem to be the case in the present experiments, since none of the patients was given insulin and was therefore presumably without insulin antibodies. It is note-worthy that the islets cultured in serum no. 3 had a lower rate of insulin and protein biosynthesis, since this serum showed a 
Table 4. Effect of normal and diabetic serum on mouse pancreatic islets cultured in medium 199 at $6.4 \mathrm{mmol} / 1$ glucose. The numbers indicate ng insulin \pm SEM per 10 islets (5 experiments). p-values are from Student's t-test for paired observations

\begin{tabular}{|c|c|c|c|c|c|c|}
\hline \multirow[t]{2}{*}{$10 \%$ serum } & \multicolumn{2}{|c|}{ Insulin release to medium } & \multirow{2}{*}{$\begin{array}{l}\text { Insulin content } \\
\text { in the islets }\end{array}$} & \multicolumn{3}{|c|}{$\begin{array}{l}\text { Insulin release per } 2 \mathrm{~h} \text { with } 5 \mathrm{mmol} / / \text { theophylline } \\
\mathrm{mmol} / \mathrm{l} \text { glucose }\end{array}$} \\
\hline & day 3 & day 5 & & 2.5 & 10 & 20 \\
\hline $\begin{array}{l}\text { N-pool } \\
D \text {-pool } \\
\text { p }\end{array}$ & $\begin{array}{l}40 \pm 6 \\
70 \pm 4 \\
<0.0025\end{array}$ & $\begin{array}{l}28 \pm 3 \\
52 \pm 4 \\
<0.0025\end{array}$ & $\begin{array}{l}197 \pm 21 \\
241 \pm 19 \\
<0.0025\end{array}$ & $\begin{array}{l}1.1 \pm 0.3 \\
2.1 \pm 0.4 \\
<0.005\end{array}$ & $\begin{array}{l}23.3 \pm 2.3 \\
28.0 \pm 2.5 \\
<0.0005\end{array}$ & $\begin{array}{l}55.8 \pm 6.7 \\
65.9 \pm 9.4 \\
<0.025\end{array}$ \\
\hline
\end{tabular}

strongly positive reaction for islet cell antibodies of the IgG class (ICA). Although the frequency of ICA among newly diagnosed insulin-dependent diabetic patients was reported to be $60-70 \%$ [8] only 2 of our 8 diabetic sera were positive. However, our material is small and further studies including the possible effect of islet cell surface antibodies, recently found to be present in $63 \%$ of newly diagnosed juvenile diabetic children [19], are required to test the significance of this observation.

Since several metabolic and hormonal parameters are abnormal in untreated diabetics, their possible $\beta$-cell stimulating effect should be considered. Although Andersson [1] showed that exposure of islets to high glucose concentrations for one week resulted in a lower maximal secretory rate in response to glucose, a somewhat elevated glucose concentration seems to be beneficial to the long-term preservation of the $\beta$-cell function in vitro $[2,9,23]$. However, the insulinotrophic effect of the diabetic sera was present even after the correction for differences in glucose concentration (Figs. 1 and 2). The apparent discrepancy between the increase in insulin content of the islets after culture in diabetic serum at $6.4 \mathrm{mmol} / \mathrm{l}$ glucose (Table 4 ) and the decrease after culture at $8.3 \mathrm{mmol} / \mathrm{l}$ glucose (Fig. 1) may be explained by our unpublished observations that a rate of insulin synthesis is obtained at a maximal glucose concentration lower than that necessary to induce a maximal rate of insulin release.

3-hydroxybutyrate is known to stimulate insulin secretion but no obvious difference was observed in insulin secretion of islets cultured in diabetic sera containing high and low 3-hydroxybutyrate (Table 1).

Several investigators have found evidence of an insulin releasing factors of hypothalamic-pituitary origin $[4,15,17,21]$. Serum growth hormone is elevated in diabetic patients before insulin treatment [13], and high concentrations $(1 \mu \mathrm{g} / \mathrm{ml})$ of human growth hormone stimulate insulin release from mouse islets maintained in tissue culture [24]. Since the serum effect remained even after a twenty fold dilution the stimulatory effect of diabetic serum seems not to be readily explained by serum growth hormone. Weereasinghe and Bornstein [25] recently reported that $\mathrm{C}$-terminal fragments of growth hormone potentiated glucose-stimulated insulin secretion from isolated islets, having earlier proposed that a C-terminal fragment was responsible for the insulin antagonistic effect of ultrafiltrates of sera from untreated juvenile diabetic patients [26]. Since intestinal hormones also stimulate insulin release [16] the occurrence of such peptides in the diabetic sera should be considered.

Finally, the adrenocorticoid hormones are known to contribute to the development and function of the endocrine pancreas in vitro [18] and we found recently that addition of hydrocortisone to isolated islets in culture resulted in an enhanced release of insulin [7]. It is possible that the elevated total corticoid content of the diabetic sera contributes to the insulinotrophic effect.

Acknowledgements. Mrs. D. Jensen, K. Brunstedt and M. Engqvist are acknowledged for their excellent technical assistance. We want to thank Drs. D. Doniach and F. Bottazzo, Dept. of Immunology, Middlesex Hospital, London for performing the islet cell antibody determinations. We are indebted to Dr. A. Lernmark for helpful criticism and suggestions during the preparation of the manuscript.

\section{References}

1. Andersson A (1974) Long-term effects of glucose on insulin release and glucose oxidation in mouse pancreatic islets maintained in tissue culture. Biochem J 140: 377-382

2. Andersson A (1978) Isolated mouse pancreatic islets in culture: Effects of serum and different culture media on the insulin production of the islets. Diabetologia 14: 397-404

3. Andersson A, Hellerström C (1972) Metabolic characteristics of isolated pancreatic islets in tissue culture. Diabetes 21 [Suppl 2]: 546-554

4. Beloff-Chain A, Hawthorn $J(1976)$ The release of insulin from pancreatic islets of lean and obese mice stimulated in vitro by pituitary glands from obese mice and by high glucose concentrations. FEBS Lett 64: 214-217

5. Berne $C$ (1975) Anti-insulin serum coupled to Sepharose $4 \mathrm{~B}$ as a tool for the investigation of insulin biosynthesis in the Bcells of obese hyperglycemic mice. Endocrinology 97 1241-1247 
6. Bottazzo GF, Florin-Christensen A, Doniach D (1974) Isletcell antibodies in diabetes mellitus with autoimmune polyendocrine deficiencies. Lancet II: 1279-1283

7. Brunstedt J, Nielsen JH (1979) Direct long-term effect of hydrocortisone on insulin and glucagon release from pancreatic islets in tissue culture. Acta Endocrinol [Suppl] (Kbh) 227: 17

8. Buschard K, Andersen OO, Christau B, Christy M, Kromann H, Nerup J, Platz P, Svejgaard A, Thomsen M, Botazzo GF (1977) Islet cell antibodies - A marker of subclinical diabetes? A pathogenic factor? Diabetologia 13: 386

9. Eff C (1978) Insulin release, insulin content, and glucose utilization in isolated mouse islets maintained in tissue culture. Acta Endocrinol (Kbh) 87: 535-542

10. Green IC, Taylor KW (1972) Effects of pregnancy in the rat on the size and insulin secretory response of the islets of Langerhans. J Endocrinol 54: 317-325

11. Hahn HJ, Menzel R, Gottschling HD, Jahr D (1976) Enhancement of glucose-stimulated insulin secretion from isolated rat pancreatic islets by human insulin antibodies. Acta Endocrinol (Kbh) 83: 123-132

12. Hales CN, Randle PJ (1963) Immunoassay of insulin with insulin antibody precipitate. Biochem $\mathrm{J} 88$ : $137-146$

13. Hanssen KF (1974) Immunoreactive growth hormone in plasma and urine in juvenile diabetics before and during initial insulin treatment. Acta Endocrinol (Kbh) 75: 50-63

14. Heding L (1972) Determination of total serum insulin (IRI) in insulin-treated diabetic patients. Diabetologia 8: 260-266

15. Hill DE, Mayes S, DiBattista D, Lockhart-Ewart R, Martin JM (1977) Hypothalamic regulation of insulin release in rhesus monkeys. Diabetes 26: 726-731

16. Johnson LR (1977) Gastrointestinal hormones and their functions. Annu Rev Physiol 39: 135-158

17. Lautala P, Ảkerblom HK, Kouvalainen K, Martin JM (1977) A hypothalamic islet-stimulating factor and childhood obesity. In: Chiumello $G$, Laron $Z$ (eds) Recent progress in pediatric endocrinology. Serono Symposia No 12. Academic Press, London, p 235-239

18. Lazarow A, Wells LJ, Carpenter AM, Hegre OD, Leonard RJ, McEvoy RC (1973) Islet differentiation, organ culture, and transplantation. Diabetes 22: 877-912
19. Lernmark $\AA$, Hägglö $B$, Holmgren $G$, Ludvigsson J (1979) Antibodies against the pancreatic $B$-cell plasma membrane in insulin-dependent diabetic children. Acta Endocrinol [Suppl] (Kbh) 227: 48-49

20. Lernmark $\AA$, Sehlin J, Täljedal I-B, Kromann $H$, Nerup J (1978) Possible toxic effects of normal and diabetic patient serum on pancreatic B-cells. Diabetologia 14: $25-31$

21. Moltz JH, Dobbs RE, McCann SM, Fawcett CP (1977) Effects of hypothalamic factors on insulin and glucagon release from islets of Langerhans. Endocrinology 101: 196-202

22. Nielsen E, Asfeldt VH (1967) Studies on the specificity of fluorometric determination of plasma corticosteroids ad modum DeMoor \& Steeno. Scand J Clin Lab Invest 20: $185-194$

23. Nielsen JH, Brunstedt J, Andersson A, Frimodt-Møller C (1979) Preservation of beta cell function in adult human pancreatic islets for several months in vitro. Diabetologia 16 : 97-100

24. Nielsen JH, Brunstedt $K$, Jørgensen $R$, Jensen D (1978) Direct long-term effect of growth hormone and prolactin on growth and function of pancreatic islets in tissue culture. Diabetologia 15: 258

25. Weerasinghe C, Bornstein J (1978) Effect of synthetic C-terminal fragments of $\mathrm{HGH}$ on insulin release by isolated islets. Am J Physiol 234: E527-E531

26. Zimmet P, Ng FM, Bornstein J, Armstrong J McD, Taft HP (1971) Insulin antagonist of pituitary origin in plasma of normal and diabetic subjects. Br Med J I: 203-204

Received: March 26, 1980,

and in revised form: September 2, 1980

Jens Høiriis Nielsen

Hagedorn Research Laboratory

Niels Steensensvei 6

DK-2820 Gentofte

Denmark 